\title{
In Vitro Investigation Regarding the Antibacterial Effects of Immunoglobulin Alone and in Combination with Antibiotics
}

\author{
Hideyo KATSUNUMA, M.D. \\ Department of Geriatric Medicine, Tokyo Medical College, Japan \\ Received 19 October 1983 \\ Accepted 28 November 1983
}

Key words: Immunoglobulin, $F\left(a b^{\prime}\right)_{2}$ fragment, Bacteriostasis, Antibacterial effects, Bactericidal

\section{Introduction}

Immunoglobulin $\mathrm{G}$ has a $\mathrm{Y}$-shaped structure in which the $\mathrm{H}$ and $\mathrm{L}$ chains are bonded together by the S-S bond. This structure of immunoglobulin $\mathrm{G}$ was discovered for the first time by Porter and Edelman, later Valentein, Green and their co-workers demonstrated this $\mathrm{Y}$-shaped structure of immunoglobulin $\mathrm{G}$ under an electron microscope, using DNP-octamethylene diamine as haptene. IgG was tried in many clinical cases of infectious diseases, but caused shock. This untoward side effect impeded further use of IgG. However, Schultz and Schwick ${ }^{6}$ and their co-workers obtained $\mathrm{F}\left(\mathrm{ab}^{\prime}\right)_{2}$ fragment by digesting the Fc fragment of IgG with the aid of pepsin. This $\mathrm{F}\left(\mathrm{ab}^{\prime}\right)_{2}$ fragment which is free from untoward side effects has been in wide clinical use in the treatment of infectious diseases, achieving remarkable results910). Today, preparations of immunoglobulin, such as sulfonated globulin and polyethylene glycol globulin, in which IgG is, both structurally and functionally, closer to native IgG, are drawing increasing attention and are in more common use.

IgG is presumed to act against infectious diseases by the following mechanisms. Firstly, IgG promotes the phagocytic activity of neutrophils and macrophages through the mediation of opsonin. Secondly, IgG destroys the cell membrane of microorganisms and acquires bacteriolytic activity through the classical or alternative pathway by activating the complement. IgG is believed to have no direct antibacterial action. On the other hand, however, there are reports (Fleming, finland, Zwisler)1) 5)7) that IgG exhibits an antibacterial action in vitro, when serum from patients, who have or have had an infection, is used alone or in combination with an antibiotic.

Because of these conflicting views, the present study has been conducted to determine whether IgG has a direct antibacterial action or not. In this study, pepsin treated immunoglobulin $F\left(a b^{\prime}\right)_{2}$ fragment, abbr. Pepsin-Ig, gamma-Venin (glycin free) which does not involve the mediation of neutrophils, macrophages or complements, were used alone or in combination with an antibiotic.

\section{Materials and Methods}

The species of microorganisms used in the present study consisted of gram-negative cocci $(K$. pneumoniae, E. coli, P. aeruginosa, H. influenzae, N. gonorrhoeae, S. marcescens) and gram-positive bacilli ( $S$. aureus, S. epidermidis, S. Faecalis). The culture media consisted of brain heart infusion (BHI) plus 2.5, 5.0 and $10 \%$ pepsin-Ig BHI, 5 and $10 \%$ albumin BHI, $12.5 \mu \mathrm{g} / \mathrm{ml}$ and $25 \mu \mathrm{g} / \mathrm{ml} \mathrm{AB}-\mathrm{PC}$ BHI, $5.0 \%$ pepsin-Ig + $12.5 \mu \mathrm{g} / \mathrm{ml} \mathrm{AB}-\mathrm{PC} \mathrm{BHI}$ and $5 \%$ pepsin $+25 \mu \mathrm{g} / \mathrm{ml} \mathrm{AB}-\mathrm{PC}$ BHI.

The inoculum sizes ranged from $1.5 \times 10^{5} / \mathrm{ml}$ to $2 \times 10^{6} / \mathrm{ml}$. 


\section{Results}

\section{Time Effect on the Viability of Incubated Gram Negative and Positive Bacteria}

1. Changes in Live Cell Count in 5\% Pepsin-Ig BHI Cultures

The time effect on the viability of gram-negative bacilli cultured in $5 \%$ pepsin-Ig BHI media is illustrated in Fig. 1. With the exception of $P$. aeruginosa and $S$. marcescens, the viability was seen to decrease in a step fashion after 1.5 hours of incubation. $N$. gonorrhoeae in particular had a remarkable loss of live cells, after 1.5 hours the live cell count had decreased to $2.0 \times 10^{3} \mathrm{cells} / \mathrm{ml}$ from the original inoculum size of $1.5 \times 10^{5}$ cells $/ \mathrm{ml}$. After 2.5 hours it was down to $3.5 \times 10^{2}$ cells $/ \mathrm{ml}$, and after 4 hours it had further decreased to $1.0 \times$ $10^{2}$ cells $/ \mathrm{ml}$.

Similary with $10 \%$ pepsin-Ig BHI media, except for the 24-hours culture of S. marcescens, the viability of gram-negative bacilli decreased with time.

On the other hand, with BHI broth cultures, and cultures with $10 \%$ albumin BHI, shown in Figs. 2 and 3 respectively, all species of organisms showed a growth with time.

2. Time Effect on the Viability of Incubated Gram Positive Bacteria

The live cell count of S. aureus cultured in 5\% pepsin-Ig BHI media decreased from $4.5 \times 10^{5} \mathrm{cells} / \mathrm{ml}$ to $2.5 \times 10^{5}$ cells $/ \mathrm{ml}$ after 4 hours, but after 24 hours had increased to $5.5 \times 10^{8}$ cells $/ \mathrm{ml}$. With $10 \%$ pepsin-Ig BHI media, S. epidermisis alone showed a decrease in live cell count, from $7.5 \times 10^{5}$ cells $/ \mathrm{ml}$ to $4.5 \times 10^{5}$ cells $/ \mathrm{ml}$ after 4 hours and down to $2.0 \times 10^{4}$ cells $/ \mathrm{ml}$ after 24 hours shown in Fig. 4 . With BHI and $10 \%$ albumin BHI media, no change in live cell count was noted in any of the cultures.

3. Changes in Bacterial Viability in 5\% Pepsin-Ig BHI Cultures after 24 Hours

Fig. 1 Proliferation-inhibitory effect on $5 \%$ pepsin-Ig BHI of gram-negative bacilli

*Pepsin Ig : Pepsin treated immcenoglobulin, $\left.\mathrm{F}(\mathrm{ab})_{2}\right)_{2}$ fragment $* \mathrm{BHI}$ : Brain heart infusion

(1) : Klebsiella pneumoniae

(2) : Escherichia coli

(3) : Pseudomonas aeruginosa

(4) : Neisseria gonorrhoeae

(5) : Hemophilus influenzae

(6) : Serratia marcescens

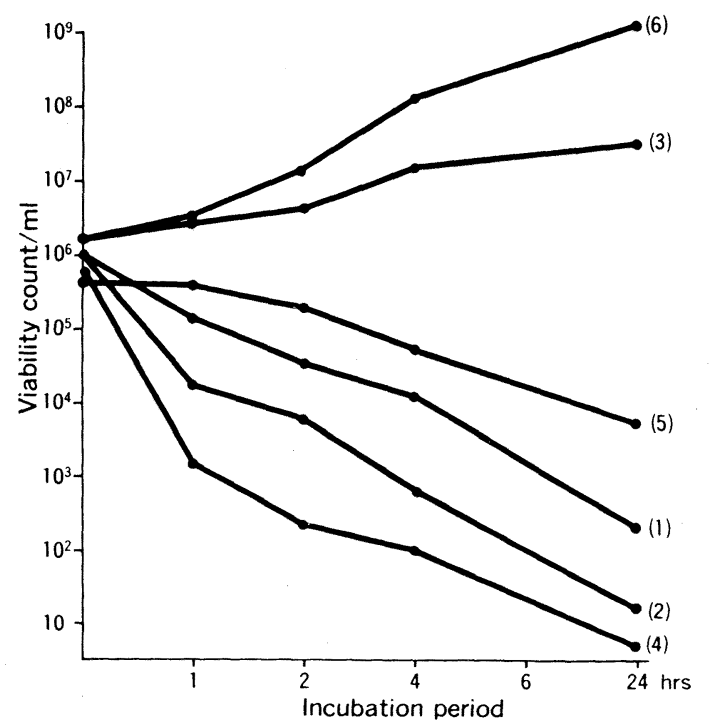

Fig. 2 Proliferation-of gram negative bacilli in the brain heart infusion $(\mathrm{BHI})$ meduim

(1) : Klebsiella pneumoniae

(2) : Escherichia coli

(3) : Pseudomonas aeruginosa

(4) : Neisseria gorrhoeae

(5) : Hemophilus influenzae

(6) : Serratia marcescescens

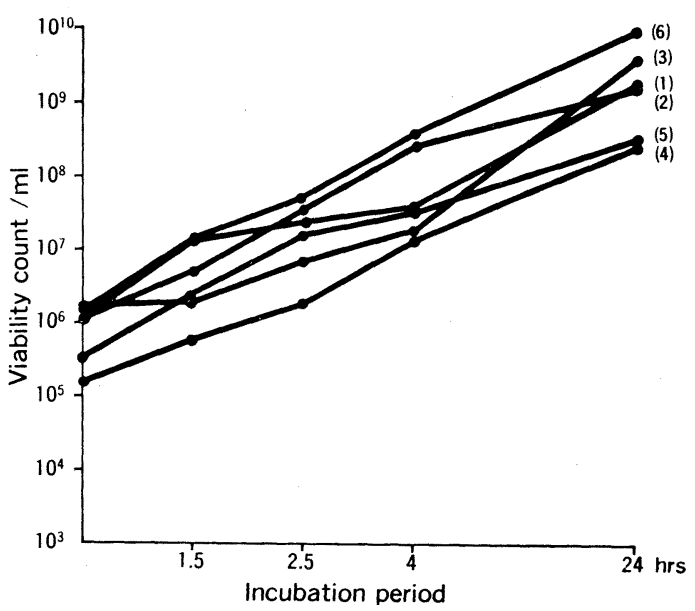


Fig. 3 Proliferation inhibitory effect on $10 \%$ albumin BHI of gram-negative bacilli

$$
\begin{aligned}
& \text { (1): Klebsiella pneumoniae } \\
& \text { (2): Escherichia coli } \\
& \text { (3): Pseudomonas aeruqinosa } \\
& \text { (4): Neisseria gorrhoeae } \\
& \text { (5): Hemophilus influenzee } \\
& \text { (6): Serratia marcescens }
\end{aligned}
$$

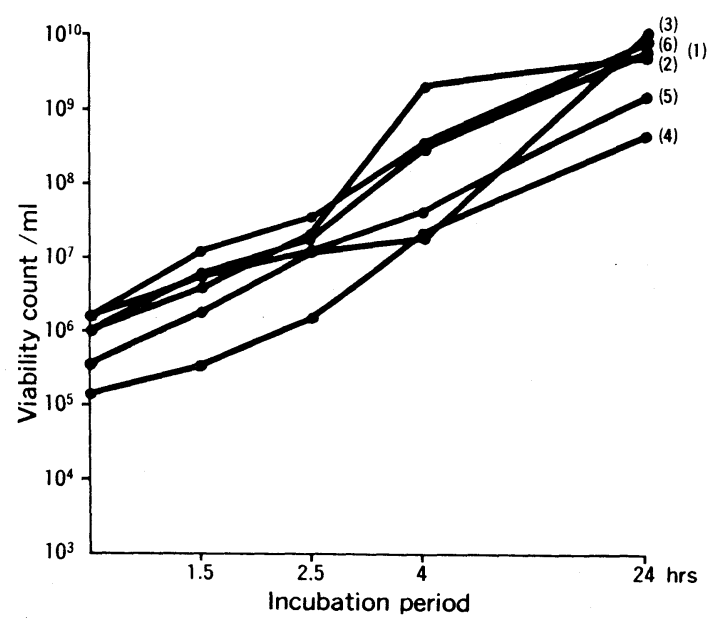

Fig. 4 Prolifetation-inhibitory effect on $5 \%$ and $10 \%$ pepsin-Ig BHI of gram-positive cocci *Pepsin Ig : Pepsin treated immcenoblobulin, Fab2fragment $* \mathrm{BHI}$ : Brain heart infusion

(1) : Streptococcus faecalis (2) : Staphylococcus aureus (3) : Staphylococcus epidermidis $\longrightarrow 5 \%$ pepsin-lg (Glysin free) BHI (1)(2)(3) $-10 \%$ pepsin-lg (Glysin free) $\mathrm{BHI}(1)^{\prime}(2)^{\prime}(3)^{\prime}$

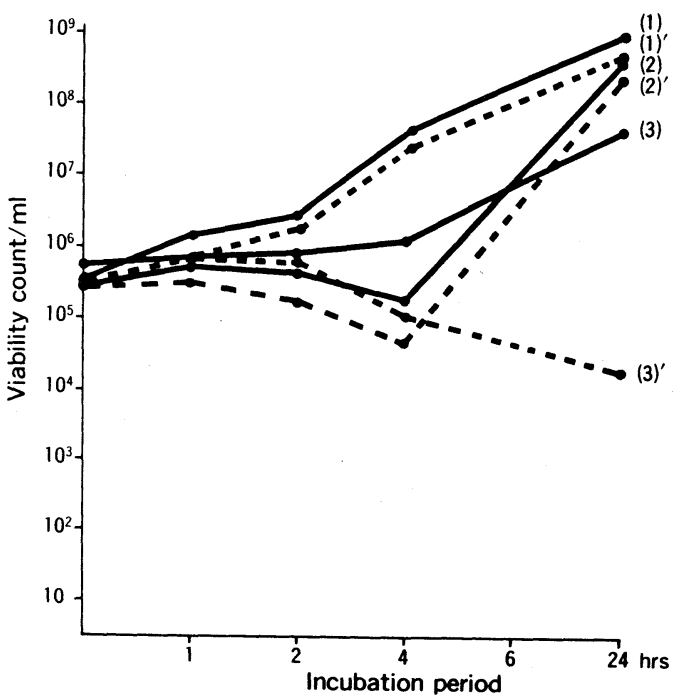

The viability of cultured bacteria decreased considerably over the first 24 hours of incubation, but then began to rise. This fact suggests that pepsin-Ig retains its bacteriostatic action for 24 hours, but has no bactericidal action.

4. Changes in Bacterial Viability with Combinations of Antibiotics

Fig. 5 Shows the results of tests with BHI and pepsin-Ig used in combination with antibiotics. The combinations tested were $\mathrm{BHI}$ alone, $5 \%$ pepsin- $\mathrm{Ig}+\mathrm{BHI}, 5 \%$ pepsin- $\mathrm{Ig}+12.5 \mu \mathrm{g} / \mathrm{ml} \mathrm{AB}-\mathrm{PC}+\mathrm{BHI}, 5 \%$ pepsin-Ig $+25 \mu \mathrm{g} / \mathrm{ml} \mathrm{AB}-\mathrm{PC}+\mathrm{BHI}, 25 \mu \mathrm{g} / \mathrm{ml}$, and $12.5 \mu \mathrm{g} / \mathrm{ml} \mathrm{AB}-\mathrm{PC}+\mathrm{BHI}$. The live cell counts after $1,2,4$ and 6 hours of incubation were all found to be lower than with BHI alone. The live cell count with $5 \%$ pepsin$\mathrm{Ig}+\mathrm{BHI}$ alone was higher than when it was combined with $25 \mu \mathrm{g} / \mathrm{ml} \mathrm{AB}-\mathrm{PC}$, although the live cell count with $5 \%$ pepsin-Ig $+\mathrm{BHI}$ alone was lower than with $12.5 \mu \mathrm{g} / \mathrm{ml}$ AB-PC BHI. The greatest reduction in live cell count was achieved with $5 \%$ pepsing-Ig $+25 \mu \mathrm{g} / \mathrm{ml}$ AB-PC + BHI media. However, even with this combination the live cell count had increased to $7.5 \times 10^{6}$ cells $/ \mathrm{ml}$ after 24 hours of incubation, as compared to the original inoculum size of $1 \times 10^{3}$ cells $/ \mathrm{ml}$.

\section{Comparison of the Test Broth Turbidity between Test Tubes with Pepsin-Ig and Test} Tubes without Pepsin-Ig

After 4 hours of incubation when the count of live bacterial cells began to decrease, the turbidity of test broth tubes with pepsin-Ig added was compared with that of test broth tubes containing no pepsin-Ig. The test broth tubes with pepsin-Ig were nearly transparent, while the tubes containing no pepsin-Ig were turbid, suggesting that without pepsin-Ig, bacteria proliferated.

\section{Smear Staining Results}

The morphology of $E$. coli with smear stain incubated with $5 \%$ pepsin-Ig revealed, after 4 hours of incubation, swollen round shape or thin elongated, shape forming filaments. In cultures without pepsin-Ig such changes were not noted. 
Fig. 5 Proliferation inhibitory effect of 5\% pepsinIg alon, combined with $\mathrm{AB}-\mathrm{PC}$ and $\mathrm{AB}-\mathrm{PC}$ alone on $K$. pneumoniae in vitro

(1) Control $\mathrm{BHI}$ medium Culture

(2) $5 \%$ Pepsin-Ig BHI

(3) $5 \%$ Pepsin-lg BHI $+12.5 \mu \mathrm{g} / \mathrm{ml} \mathrm{ABPC}$

(4) $5 \%$ Pepsin-lg BHI $+25 \mu \mathrm{g} / \mathrm{ml} \mathrm{ABPC}$

(5) $12.5 \mu \mathrm{g} \mathrm{ABPC} \mathrm{BHI}$

(6) $25 \mu \mathrm{g} / \mathrm{ml} \mathrm{ABPC} \mathrm{BHI}$

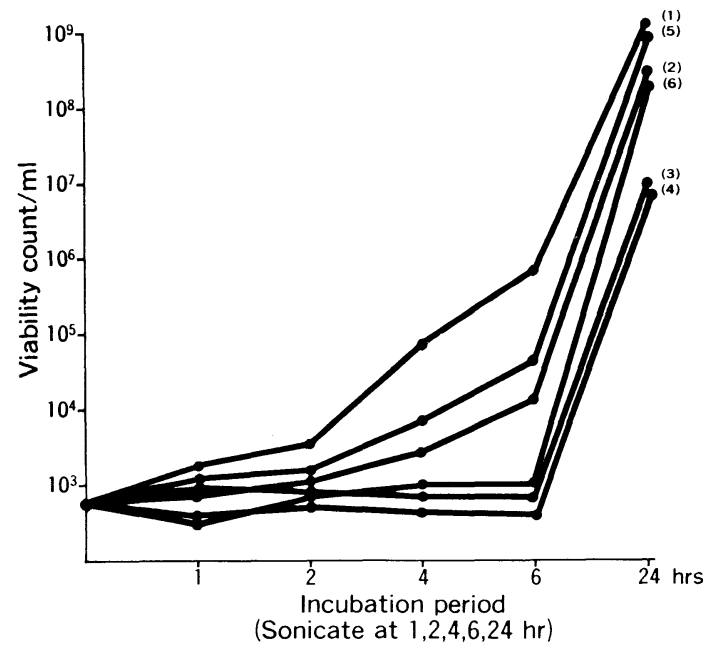

Fig. 6 Coupling of pepsing-Ig to latex beads Reagents

Pepsin Ig Lot No. 341L0256

Latex Beads $\quad \phi=0.4-0.6 \mu \mathrm{m}$ (Behringwerke)

Glycine saline

Glycine $7.51 \mathrm{~g}$

NaCl $\quad 5.85 \mathrm{~g} \mathrm{NaCl}$ $\mathrm{NaN}_{3} \quad 28$

Dissolved in $1800 \mathrm{ml} \mathrm{D.D.W.} \mathrm{and} \mathrm{adjusted} \mathrm{pH}$ to 8.2 with $0.1 \mathrm{~N} \mathrm{NaOH}$, then filled up to $2000 \mathrm{ml}$.

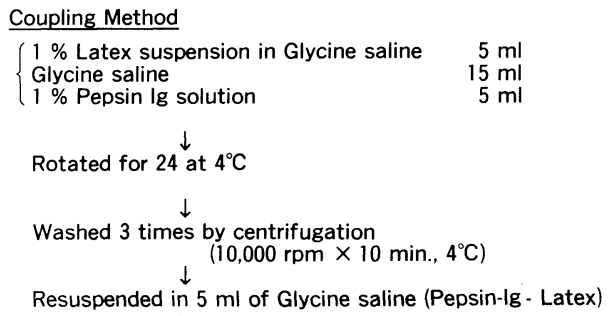

Coupling Method

$1 \%$ Latex suspension in Glycine saline $\quad 5 \mathrm{ml}$

$1 \%$ Pepsin Ig solution

$5 \mathrm{ml}$ of Glycine saline (Pepsin-lg - Latex)

\section{Experiments to Detect the Pepsin-Ig Sensitized Latex-K. Pneumoniae Complex}

Since it was shown that pepsin treated IgG had a bacteriostatic action, and produced cell swelling and filament formation when smears of $E$. coli cultures added with pepsin-Ig were stained, experiments were conducted to determine whether pepsin-Ig has a direct bactericidal action.

Experiments were designed as follows:

\section{Experiment 1:}

The pepsin-Ig coated latex was prepared by the procedure shown in Fig. 6. Briefly, $1 \%$ pepsin-Ig (glycine-free) was mixed with an equal volume of latex 0.4 to $0.6 \mu \mathrm{m}$ in diameter and incubated at $37^{\circ} \mathrm{C}$ for 4 hours then, the agglutination titer of the pepsin-Ig coated latex measured against human IgG was $2^{8}$.

To $0.5 \mathrm{ml}$ of pepsin-Ig coated latex, $2 \times 10^{8}$ cells $/ 0.5 \mathrm{ml}$ of $K$. pneumoniae were added, and the culture was incubated at $37^{\circ} \mathrm{C}$ for $15 \mathrm{~min}$. This culture was negative stained for electron microscopy.

\section{Experiment 2:}

The procedure of Experiment 2 was the same as with Experiment 1, except that BSA was used instead of pepsin-Ig.

\section{Experiment 3:}

Uncoated latex was added to an equal volume of $K$. pneumoniae to obtain a control culture and incubated at $37^{\circ} \mathrm{C}$ for $15 \mathrm{~min}$.

\section{Experiment 4:}

Latex was added to pepsin-Ig, in which the agglutination titer against $K$. pneumoniae was reduced to $2^{1}$ by the procedure shown in Fig. 7, and the culture incubated. After incubation the culture was examined for a complex of the pepsin-Ig sensitized latex and $K$. pneumoniae.

Experiment 5: Detection of the complex of anti-IgG/Fab sensitized latex and pepsin-Ig treated $K$. pneumoniae

Anti-human IgG/Fab serum (Behring Werke) was obtained, using DEAE cellulose to obtain pure anti- 
Fig. 7 Measurement of anti $K$. pneumoniae agglutination titer in IG100 and gamma-venin

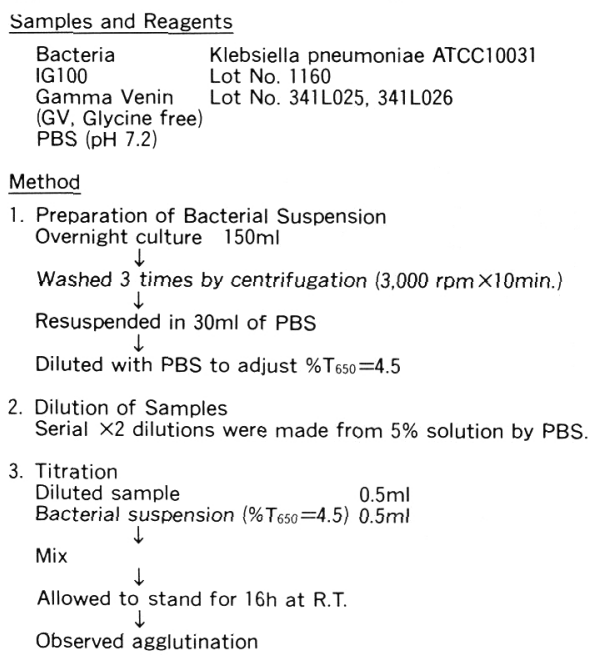

Fig. 8

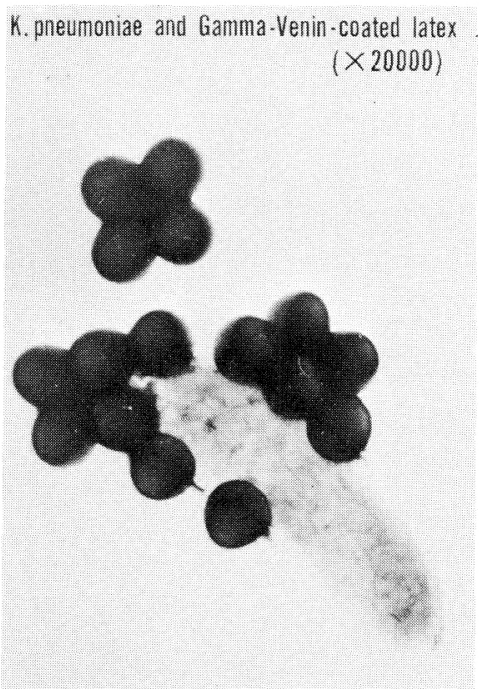

IgG/Fab fragment and adjusted to a concentration of $1 \%$ with a saline solution of glycine. An equal volume of latex was added to this solution to obtain sensitized anti-human IgG/Fab latex. It was incubated with the addition of pepsin-Ig. Washed cells of $K$. pneumoniae were added to this culture and incubated again at $37^{\circ} \mathrm{C}$ for $15 \mathrm{~min}$. After incubation the culture was studied under an microscope.

Experiment 6: Detection of the complex of anti-IgG/F $\left(\mathrm{ab}^{\prime}\right)_{2}$ specific antibody sensitized latex and pepsin-Ig treated $K$. pneumoniae

$\mathrm{F}\left(\mathrm{ab}^{\prime}\right)_{2}$ obtained from gamma-venin by filtration to allow to be bound to Sepharose $4 \mathrm{~B}$ and then added to anti-IgG/Fab and incubated to obtain specific anti-IgG/F $\left(\mathrm{ab}^{\prime}\right)_{2}$. Latex sensitized with this specific anti$\mathrm{IgG} / \mathrm{F}\left(\mathrm{ab}^{\prime}\right)_{2}$ was incubated with the addition of $K$. pneumoniae previously exposed to pepsin-Ig. After $15 \mathrm{~min}$ of incubation at $37^{\circ} \mathrm{C}$ the culture was studied under an electron microscope.

\section{Experiment 7:}

Pepsin-Ig was directly added cultures of $K$. pneumoniae and incubated. After $15 \mathrm{~min}$ of incubation the cultures were studied under an electron microscope.

\section{Electron Microscopic Findings with Neagative Stain}

The morphology of coated latex sensitized with pepsin-Ig K. pneumoniae complex revealed in experiments 1, 5, 6, and 7 that cells of $K$. pneumoniae formed complexes with latex.

In the invaded cell, cell content is released into the space between the inner and outer cell membranes, and the cell membrane is swollen as shown in Fig. 8. Further, the cell membrane is fragmented in spots and cracked shown in Fig. 9.

Fig. 10 shows that in some affected cells the outer cell membrane is separated from the cytoplasm while in Fig. 11 exuding cell content can be seen. These morphologic changes of bacterial cells exposed to pepsinIg suggest that it has a bacteriolytic action.

The cultures directly added with pepsin-Ig also showed signs of bacteriolysis as seen in Fig. 12.

With $K$. pneumoniae exposed to anti-IgG/Fab, specific anti-IgG/F $\left(\mathrm{ab}^{\prime}\right)$ sensitized latex and pepsin-Ig, latex was also observed adhering to bacterial cells. 
Fig. 9

Gamma-Venin-coated latex + K. pneumoniae

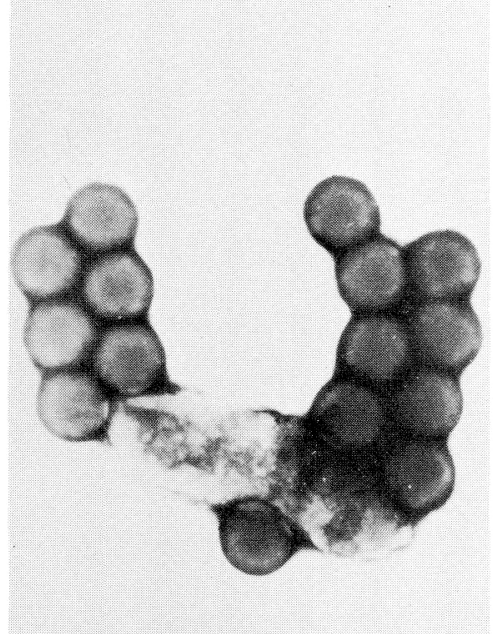

Fig. 11

Gamma Venin-coated latex $+K$. pneumoniae (Lysis of K. pneumoniae)

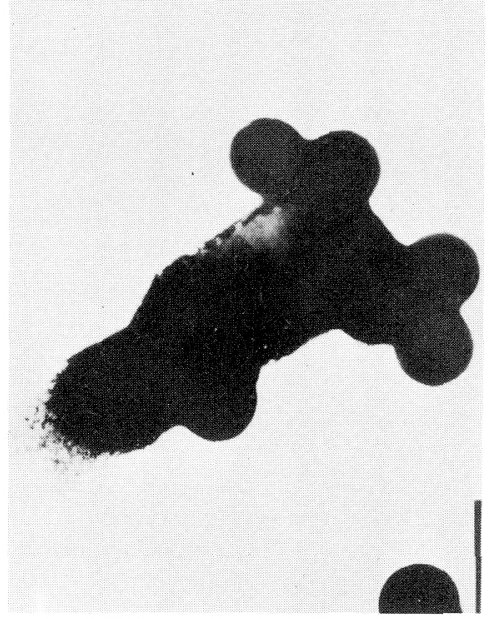

Fig. 10

Gamma-Venin-coated latex $+K$. pneumoniae

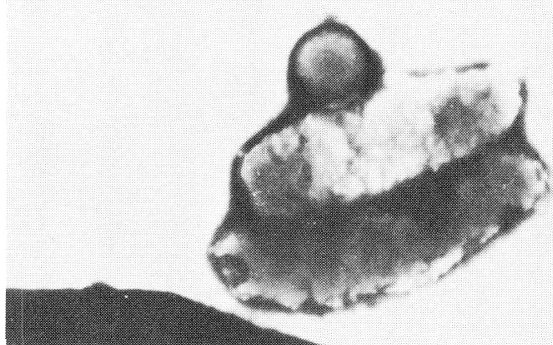

Fig. 12

Gamma-Venin + K. pneumoniae (Lysis of K. pneumoniae cell walls)

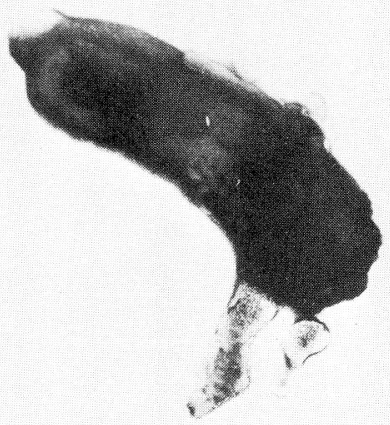

Whereas in experiments 2, 3 and 4 where uncoated latex, BSA and absorbed latex were used, no latex was seen adhering to bacterial cells (Figs. 13, 14, and 15).

In electron micrographs (Figs. 16 and 17), obtained with ultra-thin sections by uranyl-acetate staining, the outer membrane and cell wall on one side of the bacterial cell had an indistinct structure, and cytoplasm exuded around the outer cell membrane. The other side of the cell retained an intact outer membrane and cell wall structure, but apparently cytoplasm moved to the injured side, so that the intact side was void of cytoplasm. The effect of loss of cytoplasm, is that the cell membrane shrinks giving the injured cell the appearance of a cast-off snake skin left only with the membrane. 
Fig. 13

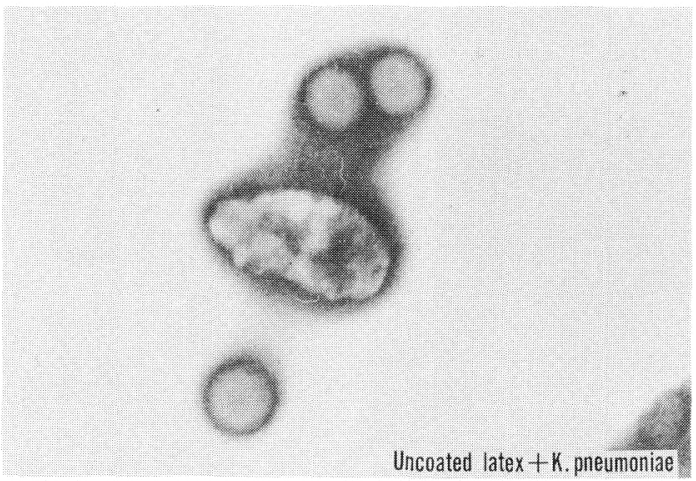

Fig. 15

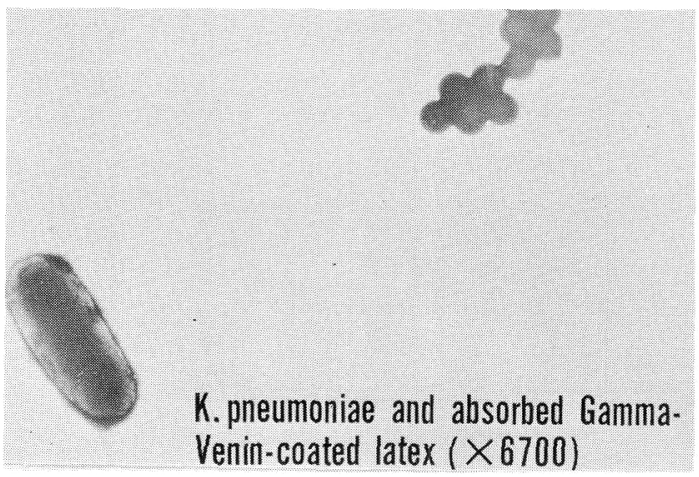

Fig. 17

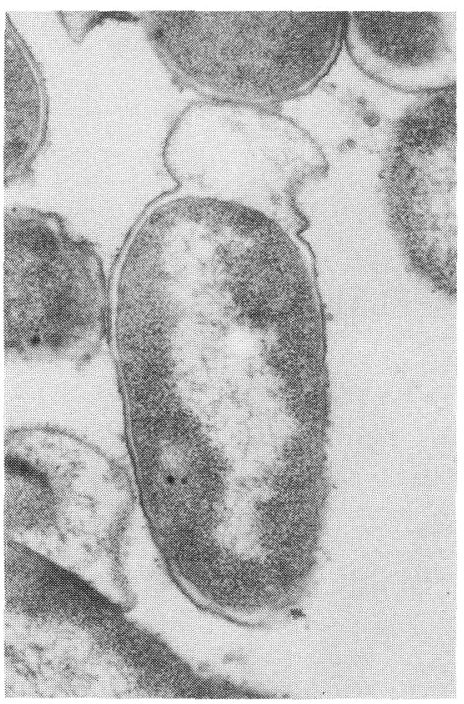

Fig. 14

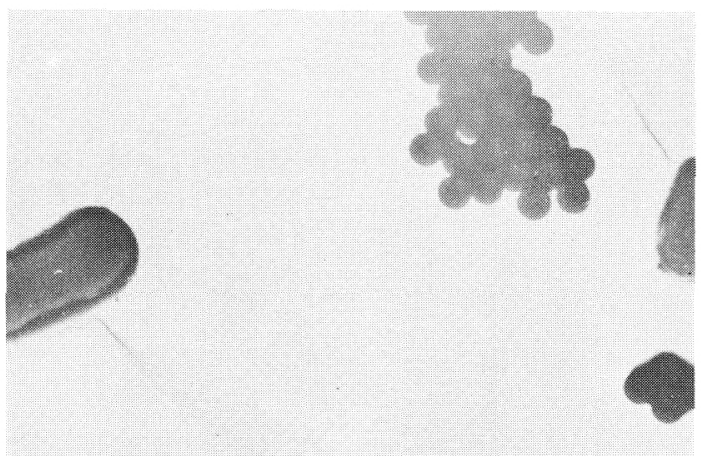

\section{K. pneumoniae and BSA-coated latex $(\times 10000)$}

Fig. 16

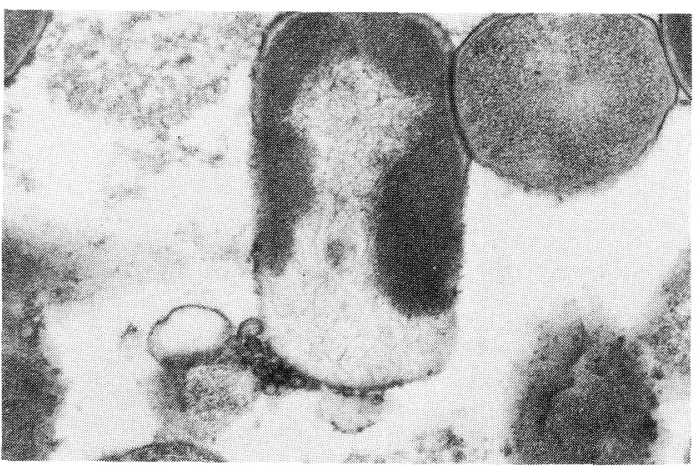

Fig. 18 Possible mechanism of bacteriostasis or bacteriolysis by attack of cell membrane and cell wall due to $F\left(a b^{\prime}\right)_{2}$ fragment immunoglobulin (pepsin-Ig)

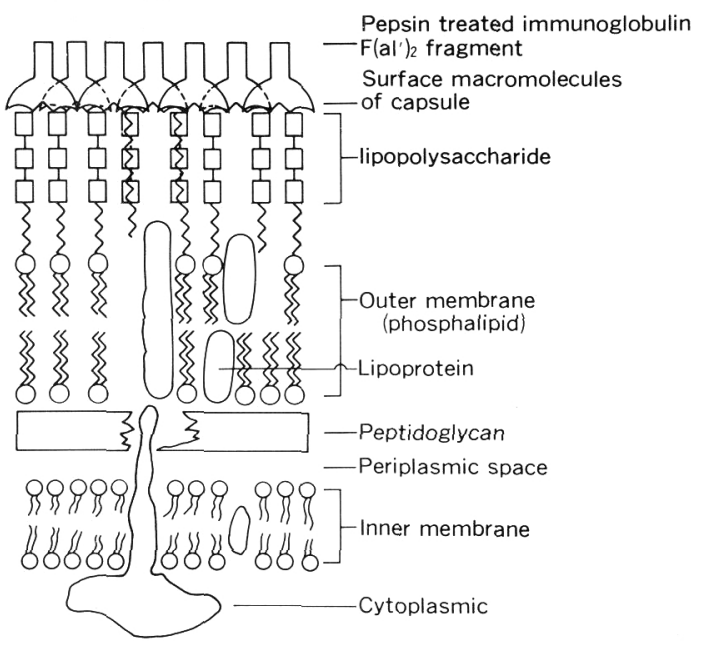




\section{Discussion}

Fleming obtained serum from a patient who had or had septic infection, and incubated it on an object glass with the addition of bacteria. Under these conditions he noted bacterial growth inhibition and, with the addition of an antibiotic of neutrophils, inhibition increased. Finland achieved bacterial growth inhibition both with $\gamma$-globulin containing a serum antibody derived from clinical material and with such $\gamma$-globulin plus an antibiotic and a sulfamide. In an in vitro experiment $Z$ wisler exposed AB-PC resistant Staphlococcus aureus to pepsin-Ig and found that pepsin-Ig inhibited bacterial growth to a greater extent than Beriglobulin. The mechanism of inhibition by pepsin-Ig has not yet been clarified ${ }^{8)}$, however.

Human IgG is presumed to act against infectious diseases by promoting the phagocytic activity of neutrophils and macrophages through the mediation of opsonin, activating the complement, and destroying the cell membrane of microoragnisms through the classical or alternative pathway, thus acquiring a bacteriolytic action. In the preasent study, to eliminate the effect of the complement, opsonin, neutrophil and macrophage, pepsin-treated human immunoglobulin (pepsin-Ig) was used. In vitro experiments pepsintreated immunoglobulin $\mathrm{F}\left(\mathrm{ab}^{\prime}\right)_{2}$ fragment showed inhibition, and some electron microscopic findings which were morphologically considered compatible with bacteriolysis were obtained. This tendency was more marked with cultures exposed to pepsin-Ig plus antibiotics.

The findings obtained in this study suggest that pepsin-Ig adheres to the bacterial cell membrane (lipopolysaccharide) and acts on the cell wall in exhibiting a bacteriostatic action and even shows a bacteriolytic effect on some weak species of organisms. It still remains for further study to clarify the mechanism of action of pepsin-Ig, however, possible mechanism of action is shown in Fig. 18. The pepsin Ig, F(ab') fragment attaches to the surface lipopolysaccharide of the outer membrane in sufficient numbers that this region of the bacteria is immobilized. Even at this stage, the bacteria can still move; such movement by other sides of the bacteria can lead to splitting of the immobilized membrane and cell wall, then through the inner membrane, resulting in cytoplasm leakage.

\section{Conclusions}

1) Pepsin-treated human immunoglobulin $F\left(a b^{\prime}\right)_{2}$ fragment, that is, pepsin-Ig, otherwise known as Gamma Venin (glycine-free) incubated containing brain heart infusion broth cultures exhibited a bacteriostatic action. When it was used in combination with antibiotics, it showed a bactericidal action.

2) When incubated cultures of pepsin-Ig sensitized latex and $K$. pneumoniae were examined under an electron microscope with negative stain, latex was found adhering to the cell membrane and injuring the cell wall. These findings were also seen in the cultures of sensitized anti-human IgG/Fab and specific anti-human $\mathrm{IgG} / \mathrm{F}\left(\mathrm{ab}^{\prime}\right)_{2}$ latex and $K$. pneumoniae.

3) Electron micrographs obtained by ultra thin section and negative stain revealed pepsin-Ig injured bacterial cell membrane and cell wall, and cells releasing cytoplasm were noted. These findings were more remarkable with pepsin-Ig used in combination with antibiotics than with pepsin-Ig alone.

4) The morphological findings of cell membrane and cell wall studies of $K$. pneumoniae under electron microscopy strongly suggested that pepsin treated Immunoglobulin $\mathrm{F}\left(\mathrm{ab}^{\prime}\right)_{2}$ fragment attacked the cell membrane or cell wall of $K$. pneumoniae inhibiting proliferation, resulting in bacteriostasis and even showed a bacteriolytic effect on some weak species of organisms.

\section{References}

1) Flemming, A.: The antibacterial action in vitro of 2 -(p-amino benzensulphonamido) pyridine of pneumococci and streptococci. Lanct. July 9: 74-78, 1983.

2) Flemming, A.: The antibacterial power of the blood of patients receiving 2-(p-aminobenzensulphonamido) pyridine. 
Lanct. Sep. 3: 564-567, 1938.

3) Finland, M. \& Brown, J.W.: Immunological studies in patients with pneumococcus type III pneumonia treated with sulfanilamide and serum. Clin. Inv. 18: 307-317, 1939.

4) Zwisler, O. \& Joacjim, I.: Amplicillinresistente Mutanten von Staph. aureus durch Gammaglobulin reduziert. Diagnostik \& Intensivetherapie 2: 11-14, 1978.

5) Ronneberger, H. \& Zwisler, O.: Verstärkung der Wirksamkeit von Antibiotika durch Immunoglobulin; tierexperimentelle Grundlagen. Fortschritte auf dem Gebiet der Antibiotika und Immunotherapie. Urban \& Schwarzenberg München p 49-61, 1982.

6) Schultze, H.E. \& Schwick, G.: Ueber neue Möglichkeiten intravenöser Gammaglobulin-Applikation. Dtsch. Med. Wscher. 87: 1643-1650, 1962.

7) Katsunuma, H. Tsurumi, N. Sakurai, N. \& Kino, T.: Combined treatment with gamma venin and antibiotics in severe infection of the elderly. Meneki to Shiikan 4: 513-522, 1982.

8) Meteger, H.: Effect of antigen binding on the properties of antibody. Adv. Immunolo. 18: 169-207, 1974.

9) Fischer, M.W. \& Manning, M.C.: Studies in immunotherapy of bacterial infections. J. Immunol. 81: 29-34, 1958.

10) Fischer, G.W. Hunter, K.W. \& Hemming, V.G.: Functional antibacterial activity of a human intravenous immunoglobulin preparation in vitro and in vivo studies. Vox Sang 44: 296-299, 1983.

\title{
試験管内に和ける免疫グロブリン単独及び抗生物質併用 による抗菌効果に関する研究
}

\author{
東京医科大学老年病学教室
}

勝 沼 英 宇

\section{要旨}

臨床的に細菌性感染症に効果を示す免疫グロブ リンの作用は，（1）opsoninを介し，宿主の好中 球, マクロファージの喰食能を促進, (2) classical 又は alternative pathwayによって補体を活性化 し溶菌作用を惹起，（3）細菌の exotoxin を中和, することによるが，菌に対しては直接殺菌作用は 有しないといわれている。本研究は pepsin 処理免 疫グロブリン, $\mathrm{F}\left(\mathrm{ab}^{\prime}\right)_{2}$ fragment, glycin free の ガンマベニン Behring werke 製（以下 pepsin Ig と略）を用い，免疫グロブリンの抗菌作用を検討 した。培地は BHI， 5 及び10\%pepsin Ig BHI, $10 \%$ アルブミン BHI を使用, 菌はグラム陰性桿 菌及び陽性球菌を用い好中球と補体を加㝋ない試 験管内菌増殖抑制の有無を経時的に観察した。

BHI 及びアルブミン BHI 培地では菌は増殖し

別刷請求先：（干160）新宿区西新宿 6-7-1 東京医科大学老年病学教室 勝沼 英宇 たが，5.0及び10.0\%pepsin Ig BHI 培地では serratia 除き，グラム陰性桿菌は何れも1.5，2.5, 4,24 時間と階段状に減少，特に $N$. gonorrhoeae は最も減少した。しかし，24時間以後は再び増殖 傾向を示した。形態学的には菌は spheroblast 化 又は filament 化した。電顕的にはアルブミン及び pepsin Igで感作していない latexには混合して 培養した $K$. pneumoniae は附着していないが, pepsin Ig で感作した latex は菌の細胞膜に附着 し，細胞内，外膜間に菌内容物が逸脱し，一部の 菌では細胞外に菌内容物流出する所見が negative stain で証明された。透過電顕でも細胞膜消 失, 破壊断裂, 菌細胞質の膜外流出が認められ, pepsin Ig による溶菌が示唆された。 以上より 5.0 又は $10.0 \%$ 免疫グロブリンにより菌は直接的に増 殖が抑制され，一部の弱いK. pneumoniae に対し て溶菌作用を認めた。 